\title{
KONSEP EKONOMI MERKANTILISME
}

Oleh : Nela Novyanti (90100118098)

Merkantilisme adalah dimana Negara ikut andil dalam melakukan peran positif dalam perekonomian dan secara langsung turut campur tangan dalam jalannya suatu perekonomian. (Hafizah, 2005)

Asal mula merkantilisme adalah pada abad ke 17, dimana terjadi perkembangan ekonomi yang sangat pesat dikalangan masyarakat baik di dalam negri maupun lintas negeri yang kemudian dikenal dengan istilah “merkantilisme”berasal dari kata merchant, yang berarti perdagangan. Paham ini menganggap bahwa setiap Negara yang ingin maju harus melakukan kerjasama dengan Negara lain. Sehingga sumber pendapatan negara akan di peroleh melalui "surplus" perdangangan luar negeri yang diterima dalam bentuk emas atau perak, sehingga kebijakaan pada saat itu ialah mendorong ekspor dan membatasi impor.

Adapun Negara-negara yang menganutp pemahaman merkantilisme pada saat itu antara lain: Portugis, Spanyol, Belanda, Spanyol dan Inggris.pada masa itu bukan hanya perdagangan yang maju pesat tetapi juga kemajuan tulisan ekonomi yang membaik dari segi jumlah maupun mutunya.

Antara Negara dan pedagang tercipta suasana saling membutuhkan. Para raja membangun dan mememlihara infrastruktur penunjang perdagangan. menjamin keselatan jalan raya untuk lalu lintas darat dan air serta menghapus beabea khusus. Pemerintah mendorong kelompok-kelompokpengusaha dengan memberikan subsidi dan hak monopoli.

Masa merkantilisme ditandai dengan periode dimana setiap orang menjadi ahli ekonomi bagi diri mereka sendiri Pendapat-pendapat Individual ini dulit digeneralisir. Dari tulisan-tulisan mereka ini Adam Smith memperoleh sumbersumber dalam menulis bukunya yang terkenl "The Wealth of Nations". 
Terdapat tiga pokok pemikiran dari teori merkantilisme ini yakn tentang neraca perdagangan, mekanisme arus logam mulia, serta proteksi dan teori kuantitas uang. Adapun tokoh-tokoh pemikir merkantilismeadalah sebagai berikut (Albanjari, 2017):

1. Jean Bodin (1530-1596) seorang ilmuan berkebangsaan Prancis yang dapat dikatakan sebagai orang pertama yang secara sistematis menyajikan teori tentang uang dan harga. Dimana penetapan harga adalah untuk memperoleh keuntungan sehingga dapat tercapai surplus. (Parakassi \& Kamiruddin, 2018)

2. Thomas Mun (1571-1641) merupakan seorang saudagar kaya yang berasal dari Inggris yang banyak menulis tetntang perdagangan luar negeri.

3. Jean Baptis Colbert(1691-1683) tujuan kebijakan yang dibuatnya lebih diperuntukan untuk kekayaaan dan kejayaan Negara dibandingkan individu.

4. Sir Wiliam Preety (1623-1687) menganggap bahwa pekrjaan atau bekerja (labor) jauh lebih menguntungkan dan penting disbanding sumber daya tanah

5. David Hume (1711-1776) merupakan sahabat Adam Smith, sering berdiskusi megenai perdagangan-perdagannya terhadap ekonomi, bukunya adalah of Balance of Trade, yang membicarakan tentang harga-harga yang sebagian dipengaruhi oleh jumlah uang. 


\section{DAFTAR PUSTAKA}

Albanjari, F. R. (2017). Pemikiran Ilmu Ekonomi ( Analisis Komparatif Ekonomi Masa Pra Klasik Dan Masa Rasulullah Saw). eksyar. Vol 4 No 1, 25-26.

Hafizah, Y. (2005). Kebijakan Ekonomi Indonesia Ditinjau Dari Konsep Dasar Ekonomi Islam. Millah. Vol 4. No 2, 33.

Parakassi, H. I., \& Kamiruddin. (2018). Analisis Harga Dan Mekanisme Pasar Dlam Perspektif Islam. Laa MaysiR Vol 5. No 1, 110. 